violater who pleaded guilty in court. The new commission cannot expect to produce a persuasive report on Galileo without going thoroughly into the question of how the Church should make up its mind about scientific issues which are at present contentious. How will the Church make up its mind about Darwinism, for example? Hankerings after directed evolution still play too big a part in the Church's view of biology. What will happen if the Big Bang turns out not to be the cosmological convenience that the Church has leaped at? It is tempting to suppose that in these enlightened days the tragedy of Galileo could not be repeated. But is that so? What is to be made of the way in which the Church, by insisting on its views of how people should behave, frequently flies in the face of what is known about human behaviour? Only last Sunday, Pope John-Paul II, a charismatic publicist but an illiberal pope, was asking that remarried people should refrain indefinitely from sexual intercourse. The Church's views on birth-control, appropriate enough when the chances of newborn children reaching puberty were a good deal less than fifty per cent, are now a means of making millions small-time martyrs, pathetic contemporary analogues of Galileo. The Poupard commission will steer away from cans of worms like these. In doing so, it will fall far short of what seem to be its objectives.

\title{
Solutions for transatlantic universities?
}

Everybody agrees that higher education is important. Many people spend time worrying about its health. Almost nothing is being done. This, it seems, is the lesson to be drawn from the clutch of reports on higher education published in the past few days. The meeting organized by the European Community at Strasbourg last week (see page 773) was presented with a familiar analysis of what the future holds (see Nature, 23 October); immobile university teaching staffs unlikely to be renewed on a substantial scale for years ahead, indefinitely straitened budgets and declining student numbers. What the commission's working paper did was to extend to the whole of Europe the gloomy analysis of the future for British universities described just over two years ago when Mrs Shirley Williams was Secretary of State for Education and Science. According to temperament, some academics (and some of their well-wishers) will be heartened to know that misfortune is so widespread while others will be dismayed that the problem is so huge.

Yet the problem is also unchanging, or apparently so. This week's report from the House of Commons Select Committee on Education (see page 770) makes that plain. The committee is still urging action on issues that first became urgent years ago. Has the dual support system for research quite broken down, and if so why? Can something be done to make the Universities Grants Committee a better buffer between the universities and central government? What should be done to help universities deal with the inflexibility that demography has thrust upon them? The committee has some sensible and even original things to say. Whether they will evoke a response from government departments whose present concern is what it seems continuously to have been for the past several years - to find further economies in public spending - is another matter.

Only in the United States does it seem that optimism survives and even that may be illusory. The report on science and engineering education put together for the White House by the National Science Foundation and the Department of Education (see page 769) is no doubt right to deny some of the wilder fears about the adequacy of higher education in the United States - the charge that the efficacy of United States defence may be jeopardized by the quality of graduates from the universities for example. Moreover, there is no substance in the wish that some sleight of hand by university administrators might of itself beat back the tide of imports from Japan and elsewhere. If the United States is slipping as an economic power, it is largely because its people have elected to enjoy more of the benefits of service industries than the people of states such as Japan (see Nature, 2 October). The White House report nevertheless discovers a number of points at which the university system is under stress. The difficulty of persuading engineers to teach other engineers is not an isolated problem but a sign that universities may chronically be least able to recruit the teachers whose services are most needed. And if the terms of reference of the study had been wider, it would probably have come to conclusions that echoed, perhaps less starkly, those of European commentators - ageing teaching staffs, too much immobility among them and the prospect of too few students. What on earth is to be done?

Times like the present, when most governments are preoccupied with serious financial problems, are not propitious for grand designs for reform. Radical and sweeping change is easiest when funds are plentiful. The most serious danger in the prolongation of present difficulties, however, is that university systems on both sides of the Atlantic will be further impoverished in their present pattern until change heralded by crisis is forced upon them. This is why, while waiting for the grand design, some of the common problems of these several university systems need to be tackled piecemeal and empirically.

The question of academic tenure is an obvious problem, with which American universities have grappled for several years. The House of Commons committee deals with the issue judiciously. Tenure is an essential ingredient of academic freedom, but there is no reason why a university that no longer needs a whole department should not invite the teachers concerned to leave, on terms regarded by their academic colleagues as equitable or even generous. Most European academics will resist this notion, familiar though it has unhappily become in the United States. Yet if the choice is between the health of a university and the discomfort of some of its academics, can lifelong tenure be justly held always to be beneficent? European universities are mostly too mealy-mouthed on this delicate subject - and too free with early tenure in any case.

Shortages of teachers in specialized subjects, identified in engineering by the White House report, are commonplace and also chronic. They are, however, by no means as novel as they seem - both in medicine and the law, most university systems have special devices for persuading high-earning professional people to devote themselves partly to the interests of students, their future competitors. In more novel fields, systems engineering for example, there has not been - and probably will not be - time for suitable inducements to be devised. Universities may have to manage indefinitely with unconventional solutions. Part-time teachers drafted in from industry may help but will not solve all the problems that abound. The general solution must however be more flexible and permanent. Is it not time that universities hard-pressed to teach students what only industries know and practise should, without shame, arrange to have their students taught vocational skills on the job?

Another conspicuous element of the common malaise is that universities are no longer as autonomous as they like corporately to pretend. Especially in Europe but also in parts of the United States system, external agencies have an increasing say in the development of policy. The explanation is simple - governments pay an increasing share of the costs, and expect an increased influence. Yet governments, however liberal, are less able to know what are the needs of individual universities than are the academics who work in them. In principle, academics are also best placed to judge their contribution to national needs, and their places in the university systems to which they belong. The precondition, however, is autonomy - the freedom to make decisions for themselves. In this sense, the demand that universities should be free from some of the shackles that at present bind them is not a demand for the right to irresponsibility but the opposite. More autonomy is certain to mean better universities. 